\title{
RELASI AGAMA DAN NEGARA PERSPEKTIF KH. A. WAHID HASYIM DAN RELEVANSINYA DENGAN KONDISI SEKARANG
}

\author{
Rijal Mumazziq Zionis \\ Institut Agama Islam Negeri Jember, JI. Mataram No. I, Jawa Timur 68|36 | \\ rijalmz@gmail.com
}

\begin{abstract}
KH}$. A. Wahid Hasyim is a progressive and a dynamic Muslim thinker. As a Muslim scholar, he was consistent in his Islamic thought. At the same time, as a statesman, he put the unity of the nation above anything else. The struggle that is worth to be noted here is that although he offered Islam as the state principle by supporting the inclusion of the seven clauses of the Jakarta Charter, but he was willing to remove the seven clauses for the sake of securing unity and integrity of the nation. In Islamic political theory, he is classified as a substantive thinker who supported the symbiotic relationship between religion and state. Up to now, his thought remains relevant to be implemented in the context of the relationship between religion, nation, and state. It is not enough to justly read and examine KH.A. Wahid Hasyim's thought, the most important thing is how to apply his idea in Islamic and Indonesia context. He advocated moderation (tawazun), tolerance (tasamuh), middle way (tawassuth), and fairness (i'tida). These values should always be adopted since they are the inclusive and accommodative principles for the life of the nation. Thus, those principles are still relevant for present Indonesia.
\end{abstract}

Keywords: $\mathrm{KH}$. Wahid Hasyim, religion and state relationship, current condition

Abstrak: KH. A. Wahid Hasyim merupakan pemikir progresif dan dinamis. Sebagai agamawan, ia konsisten dalam pemikiran keislaman. Sebagai negarawan, ia mengutamakan persatuan dan kesatuan bangsa. Pengorbanan yang layak dicatat adalah meskipun ia memperjuangkan Islam sebagai dasar negara dengan mendukung pencantuman tujuh anak kalimat dalam Piagam Jakarta, namun ia rela menghapus tujuh kata itu, demi mengutamakan persatuan dan keutuhan bangsa. Dalam 
khazanah keilmuan politik Islam, ia tergolong pemikir substansialis yang mendukung relasi agama dan negara dalam corak relasi simbiotik. Hingga kini, pemikiran puluhan tahun lalu itu tetap relevan diimplementasikan dalam konteks beragama, berbangsa dan bernegara. Tak cukup hanya membaca dan mengkaji pemikiran $\mathrm{KH}$.A. Wahid Hasyim, yang lebih penting adalah mengaplikasikan gagasangagasan KH.A.Wahid Hasyim dalam konteks keislaman dan keindonesiaan. Sikap dan pandangan moderat (tawazun), toleran (tasamuh), mengambil jalan tengah (tawassuth), dan bersikap adil ('tidal), yang dianut merupakan pilihan tepat yang inklusif dan akomodatif dalam kehidupan berbangsa dan bernegara. Dengan demikian, sikap dan pendangannya masih relevan untuk diimplementasikan dalam kondisi sekarang. Pribadi, jejak langkah dan perjuangan KH.A. Wahid Hasyim, sebagai tokoh besar, layak untuk diteladani.

Kata Kunci: KH. Wahid Hasyim, relasi agama dan negara, relevansi dengan kondisi sekarang

\section{Pendahuluan}

Wacana tentang relasi agama dan negara, seolah tiada habisnya. Perbincangan tersebut, senantiasa aktual dan faktual seiring dengan berlakunya konsepsi ajaran agama Islam yang multi interpretasi. Oleh karena itu, meskipun sudah banyak uraian yang diberikan tentang konsepsi relasi agama dan negara, upaya untuk mencari format yang memungkinkan akan selalu layak untuk diperbincangkan dan diperdebatkan. Sebab, meskipun Islam menekankan keselarasan kehidupan di dunia dan akhirat, namun landasan teks keagamaan untuk membentuk sebuah negara masih bisa diperdebatkan. Sehingga munculnya beberapa kelompok umat Islam dalam menafsirkan ajaran agamanya berkaitan dengan sistem politik dan pemerintahan merupakan sesuatu yang bisa dimengerti.

Diskursus relasional itu terus terjadi karena alasan bahwa entitas ini sama-sama memiliki 'pengikut' dan kepentingan masing-masing. Kuatnya arus perdebatan ini dikarenakan agama memiliki nilai sakral, karena itu seringkali diagungkan dan 
diunggulkan untuk menjadi rujukan bagi para pemeluknya. Sementara politik, di sisi lain, adalah semacam kekuatan pemaksa yang sangat berpengaruh dalam aktivitas kenegaraan. Dengan politik orang dapat mengatur orang lain, karena dia memiliki kekuasaan. Sedangkan negara, dengan model dan caranya sendiri memiliki kekuatan yang cukup dahsyat dalam mengatur masyarakatnya sebagai dasar legitimasi kekuasaan politik yang dimiliki. ${ }^{1}$

Banyaknya upaya yang telah dilakukan para ulama dalam rangka pencarian format relasi agama dan negara, pada dasarnya mengandung dua maksud. Pertama, untuk menemukan idealitas Islam tentang negara (menekankan aspek teoritis dan formal), yaitu dengan menjawab pertanyaan, "Bagaimana bentuk negara dalam Islam?". Pendekatan ini bertolak pada suatu asumsi bahwa Islam memiliki konsep tertentu tentang negara. Kedua, untuk melakukan idealisasi dari perspektif Islam terhadap proses penyelenggaraan negara (menekankan aspek praktis dan substansial), yakni mencoba menjawab pertanyaan, "Bagaimana isi negara menurut Islam?".

Maka pertanyaan-pertanyaan di atas pada akhirnya melahirkan tiga kategorisasi pemikiran mengenai hubungan agama dan negara. Dalam perspektif Munawir Sjadzali, setidaknya terdapat tiga aliran dalam relasi agama dan negara. Pertama, aliran konservatif, yang tetap mempertahankan integrasi antara agama dan negara. Aliran ini berpendapat bahwa Islam telah lengkap secara paripurna dalam mengatur sistem kemasyarakatan, termasuk di dalamnya masalah politik. Dalam paradigma integralistik, agama dan negara menyatu. Karenanya kepala negara adalah pemegang kekuasaan agama dan kekuasaan politik. Pemerintahannya diselenggarakan atas dasar "kedaulatan Ilahi" (divine soveregnity), karena kedaulatan berasal dan berada di "tangan Tuhan".

' Listiono Santoso, Teologi Politik Gus Dur, (Yogyakarta: Arruz Press, 2004), 182. 
Kedua, aliran modernis, aliran ini berpendapat bahwa Islam hanya mengatur masalah kemasyarakatan secara garis besarnya saja, sedangkan teknis pelaksanaannya bisa saja mengadopsi sistem lain. Dengan kata lain, corak pemikiran yang juga disebut simbiotik ini, agama memerlukan negara, karena dengan negara, agama dapat berkembang. Sebaliknya, negara juga memerlukan agama, karena dengan agama negara dapat berkembang dalam bimbingan etika dan moral-spiritual.

Ketiga, aliran sekuler, yang berusaha memisahkan agama dan negara. Menurut aliran ini, Islam sebagaimana agama-agama lainnya, tidak mengatur masalah keduniaan, sebagaimana yang terdapat dalam masyarakat Barat. ${ }^{2}$ Paradigma sekularistik mengajukan pemisahan (disparitas) agama atas negara dan pemisahan negara atas agama.

Dari aspek sejarah, hubungan agama, terutama Islam di Indonesia, dengan negara pada sebagian merupakan cerita antagonisme dan kecurigaan satu sama lain. Hubungan yang kurang harmonis ini, terutama, tetapi tidak seluruhnya merupakan akibat dari perbedaan pandangan founding fathers, mengenai bentuk negara Indonesia yang dicita-citakan. Salah satu butir terpenting dalam perbedaan pendapat di atas adalah apakah negara ini bercorak "Islam" atau "nasionalis". ${ }^{3}$

\footnotetext{
${ }^{2}$ Ketiga kategori ini mengikuti pola yang dibuat oleh Munawir Sjadzali yang kemudian diikuti oleh Masykuri Abdillah. Ketiga kelompok itu, yang oleh Munawwir tidak dimasukkan ke dalam term politik tertentu, menurut Masykuri terbagi menjadi tiga; Konservatif, Modernis dan Sekuler. Sementara Bahtiar Effendi mengelompokkannya dalam dua spektrum pemikiran : formal idealistik dan substansial realistik. Berbeda dengan Munawir, M Din Syamsudin membaginya dalam ke dalam tiga paradigma. Masing-masing adalah integralistik, simbiotik, dan sekularistik. Baca Munawir Sjadzali, Islam dan Tata Negara; Ajaran, Sejarah dan Pemikiran, (Jakarta: UI Press, 1993), I-3; begitu pula Masykuri Abdillah, Demokrasi di Persimpangan Makna: Respon Intelektual Muslim Indonesia Terhadap Demokrasi (1966-1993), (Yogyakarta: Tiara Wacana, 1999), 57; bandingkan dengan Bahtiar Effendi, Islam dan Negara: Transformasi Pemikiran dan Praktik Politik di Indonesia, (Jakarta: Paramadina, 1998), 6-15. Bandingkan dengan M. Din Syamsudin, Usaha Pencarian Konsep Negara dalam Sejarah pemikiran Politik Islam, dalam Jurnal Ulumul Quran, (Nomor 2, vol IV, th 1992), 4-7.

${ }^{3}$ Kedua corak pemikiran kenegaraan ini ini diungkapkan oleh Bahtiar Effendi. Lihat Bahtiar Effendi, Islam dan Negara: Transformasi Pemikiran, 60.
} 
Perdebatan berlangsung tatkala para founding fathers yang tergabung dalam BPUPKI (Badan Penyelidik Usaha-Usaha Persiapan Kemerdekaan Indonesia, Dokuritsu Zyunbi Tyoosakai) membahas bentuk dasar negara dan bentuk pemerintahan. ${ }^{4}$ Dari 62 anggota BPUPKI, terbagi dua arus besar; golongan nasionalis sekuler serta nasionalis Islami. Namun, dari jumlah itu, hanya 25 $\%$ saja yang dianggap mewakili kepentingan Islam, selebihnya mewakili pandangan nasionalisme sekuler yang dalam hal ini enggan membawa agama dalam masalah kenegaraan. Sehingga tampaknya dukungan pemerintah pendudukan Jepang kepada Islam tak dapat lagi diharapkan. ${ }^{5}$

KH.A. Wahid Hasyim salah seorang intelektual muda pesantren dan tokoh NU, termasuk dalam barisan nasionalis Islam dalam BPUPKI bersama Abikusno Tjokrosujoso (Sarekat Islam), Kahar Muzakkir (Muhammadiyah), Agus Salim (PII). Mereka mempelopori disahkannya Piagam Jakarta, setelah melalui perdebatan panjang. Keempat orang ini, secara ideologis berseberangan dengan kelompok nasionalis sekuler seperti Soekarno, M. Hatta, M Yamin, A Soebardjo, serta AA Maramis. ${ }^{6}$

Dari latar belakang peristiwa di atas, kita dapat melihat apa yang dilakukan KH. A. Wahid Hasyim sangat penting dan menarik, sebab di antara beberapa usulnya adalah dicantumkannya Islam secara formal sebagai agama negara disertai syarat bahwa presiden harus orang Islam. Selain itu, upaya formalisasi Islam sebagai agama negara juga tampak dalam proses perumusan dan pengesahan Piagam Jakarta.

${ }^{4}$ Endang Saifuddin Anshari, Piagam Jakarta 22 Juni 1945 dan Sejarah Konsensus Nasional Antara Nasionalis Islami dan Nasionalis Sekular Tentang Dasar Negara Republik Indonesia 1945-1959, (Bandung: Penerbit Pustaka, 1983), 26.

5 Ibid., 26; Lihat pula Prawoto Mangkusasmito, Perumusan Historis Rumus Dasar Negara dan Sebuah Proyeksi, (Jakarta: Hudaya, 1970), 12. Sebagai pembanding lihat juga Harry J. Benda, Bulan Sabit dan Matahari Terbit: Islam Indonesia Pada Masa Pendudukan Jepang, (Jakarta: Pustaka Jaya, 1980), 222-244.

${ }^{6}$ B.J. Boland, Pergumulan Islam di Indonesia 1945-1972, (Jakarta: Grafiti Press, 1985), 29. 
Meski sebelumnya bersikukuh menempatkan Islam sebagai dasar negara, KH.A. Wahid Hasyim justru menyetujui penghapusan tujuh kata itu dari UUD 1945. Terlepas dari polemik dan kontroversi yang seputar kehadiran KH.A. Wahid Hasyim pada 18 Agustus itu, tak dapat diragukan bahwa peran dan kontribusi KH.A. Wahid Hasyim dalam perumusan dasar negara menjadi sangat signifikan.

Selain dikenal sebagai agamawan, tokoh pembaru pesantren ${ }^{7}$ dan negarawan, ${ }^{8}$ satu hal yang pantas dikagumi dari sosok KH.A. Wahid Hasyim adalah produktifitasnya sebagai penulis. Tulisannya padat, tajam, dan kritis. Sebagai seorang pemimpin Islam yang produktif menulis, ia mengungkapkan pendapatnya dalam berbagai perspektif; dari agama, politik, masyarakat, dan berbagai persoalan kebangsaan, terutama pada pergerakan nasional di masa revolusi. Sebagai pemikir berlatar belakang keislaman yang kuat, seringkali ia menyitir ayat dan hadith. Acapkali ia juga mengggunakan pendekatan sosiologi dan filsafat. Selain mengunakan nama asli, kadangkala ia menulis dengan menggunakan nama samaran. Berbagai tulisannya telah terangkum dalam Sejarah Hidup KH. KH.A. Wahid Hasyim dan Karangan Tersiar, ${ }^{9}$ dan Mengapa Memilih NU: Konsepsi tentang Agama, Pendidikan dan Politik. ${ }^{10}$ Mengenai tulisan-tulisan KH.A. Wahid Hasyim, Saifullah Ma'shum menilai bahwa :

\footnotetext{
${ }^{7}$ Substansi dari ide pembaharuan yang dikemukakan K.H..A. Wahid Hasyim adalah perubahan paradigmatik pesantren sekaligus madrasah saat itu. Achmad Zaini mengklasifikasikan pembaharuan paradigma tersebut ke dalam tiga kelompok; paradigma teosentris ke antroposentris, paradigma dikotomik ke non dikotomis, dan paradigma teoritis menuju praktis. Selengkapnya baca karya Achmad Zaini, Kyai Haji Abdul Wahid Hasyim; His Contribution To Moslem Educational Reformand Indonesian Nationalism During The Twentith Century, (Yogyakarta, Titian llahi Press, 1998). Serta Rochman Basori, The Founding Father Pesantren Modern Indonesia; Jejak Langkah KH. A. Wahid Hasyi, (Banten, Inceis, 2006).

${ }^{8}$ Sutjianingsih, KH.A. Wahid Hasyim, (Jakarta: Depdikbud, 1984), 3-8.

9 Berbagai tulisan KH.A. Wahid Hasyim ini berhasil dihimpun oleh Aboebakar Atjeh. Lihat Aboebakar Atjeh, Sejarah Hidup K.H.A. Wahid dan Karangan Tersiar, (Jakarta: Panitia Buku Peringatan Alm. K.H.A. Wahid Hasyim, 1957).

10 KH.A. Wahid Hasyim: Mengapa Memilih NU, Konsepsi tentang Agama, Pendidikan dan Politik, Buntaran Sanusi dkk (Ed.)
} 
Pertama, betapa Abdul KH.A. Wahid Hasyim memiliki jiwa toleransi yang tinggi terhadap perbedaan paham dan bersikap proporsional dalam menyikapi setiap persoalan yang dihadapi; Kedua, besarnya kepedulian terhadap peningkatan kualitas hidup umat Islam; dan Ketiga, adalah sikap kritisnya yang tak pernah padam meskipun menyangkut umat Islam sendiri. Melalui tulisannya, kita menangkap getaran keprihatinan yang sangat dari KH.A. Wahid Hasyim setiap dia menyaksikan kondisi umat Islam ketika itu. ${ }^{11}$

Saifuddin Zuhri, salah satu kader didikan KH.A. Wahid Hasyim dan Mantan Menteri Agama mengungkapkan kekagumannya pada tulisan-tulisan gurunya :

"Tulisan-tulisannya itu melukiskan betapa jauh pandangannya ke depan serta betapa luas pengetahuannya. Ditulis dengan gaya populer, ilmiah dan dalam susunan gaya bahasa yang bagus sekali. Dibentangkannya, misalnya, tentang bagaimana kedudukan kita di tengah-tengah kancah perjuangan, ke mana jalan yang hendak kita tuju, manfaat apa yang bakal kita capai, tetapi juga resiko apa yang akan kita hadapi. Uraiannya jelas, mantap, dan sangat mengesankan."12

Sejalan dengan apa yang diungkapkan oleh Ma'shum dan Zuhri, Abdurrahman Mas'ud melihat KH.A. Wahid Hasyim sebagai seorang ulama yang mampu berpikir ke depan (visionerfuturistik) dengan ide-ide besarnya yang orisinil. Namun, ia menilai mengkaji pemikiran KH.A. Wahid Hasyim tak mudah. Sebab, meskipun ia ulama intelektual yang produktif, namun sayang pemikiran-pemikirannya banyak yang tak terpublikasikan. ${ }^{13}$

Dalam konteks perjuangan kebangsaan Indonesia, keberadaan dan peranan yang dimainkan KH.A. Wahid Hasyim begitu signifikan dalam membangun dan membangkitkan

" Saifullah Ma'shum (ed), Menapak Jejak Mengenal Watak. Sekilas Biografi 26 Tokoh Nahdlatul Ulama, (Jakarta: Yayasan Saifuddin Zuhri, 1994), 310-3II.

12 Saifuddin Zuhri, Guruku Orang-Orang Dari Pesantren, (Yogyakarta: Yayasan Saifuddin Zuhri dan LkiS, 200I), II3-II4.

13 Abdurrahman Mas'ud, "Kata Pengantar" dalam Rochman Basori, The Founding Father Pesantren Modern Indonesia; Jejak Langkah KH.A. Wahid Hasyim, vii 
semangat kebangsaan dan pemahaman yang utuh tentang keagamaan pada masyarakat Indonesia. Sehingga masyarakat akan lebih mengerti tentang Islam yang sesungguhnya. Penyikapan inilah yang kemudian melahirkan sikap nasionalisme yang dilandasi nilai-nilai keislaman.

\section{Relasi Agama dan Negara}

Istilah relasi, dalam penelitian ini diartikan sebagai "hubungan"; "perhubungan", dan "pertalian". ${ }^{14}$ Sedangkan "Agama" mengandung pengertian bahwa ia adalah suatu peraturan yang mengatur kehidupan manusia agar tidak kacau. ${ }^{15}$ Sedangkan negara, secara terminologi diartikan dengan organisasi tertinggi di antara satu kelompok masyarakat yang mempunyai cita-cita untuk bersatu, hidup di dalam daerah tertentu dan mempunyai pemerintahan yang berdaulat. Pengertian ini mengandung nilai konstitutif dari sebuah negara yang meniscayakan adanya unsur dalam sebuah negara, yakni adanya sebuah masyarakat (rakyat), adanya wilayah (daerah), dan adanya pemerintah yang berdaulat. ${ }^{16}$

Definisi di atas, tampaknya dapat dijadikan sebagai langkah awal dalam penelitan ini guna melacak istilah negara dalam khazanah Islam. Sebab, dalam kajian Islam (Islamic studies), istilah negara bisa bermakna dawlah, ${ }^{17}$ khilafah, ${ }^{18}$ imamah ${ }^{19}$ hukumah, ${ }^{20}$ dan kesultanan. $^{21}$

14 Tim Penyusun Kamus Pusat Pembinaan dan Pengembangan Bahasa, Kamus Besar Bahasa Indonesia, Edisi II, (Jakarta: Balai Pustaka, 1994), 830.

15 Berasal dari bahasa Sansekerta "a" berarti tidak, dan "gama" berarti kacau. Lihat Harun Nasution, Islam Ditinjau dari Berbagai Aspeknya, jlid I, Vol I, (Jakarta: UI Press, 1974), 10.

${ }^{16}$ Ahmad A. Hafizar Hanafi, Tata Negara, (Jakarta: Yudhistira, 1995), 19.

${ }_{17}$ Berasal dari bahasa Arab, yakni dawlat, akar katanya berasal dari dalla-yadullu-dawlat yang berarti "bergilir", "beredar", dan "berputar". Dapat diartikan sebagai kelompok sosial yang menetap pada suatu wilayah tertentu dan diorganisir oleh suatu pemerintahan yang mengatur kepentingan dan kemaslahatan. Lihat Abdul Aziz Dahlan, Ensiklopedi Hukum Islam, jilid I, (Jakarta: Ichtiar Baru van Hoeve, 1996), 262.

${ }^{18}$ Berasal dari kata khalf, yang berarti "wakil", "pengganti", atau "penguasa". Istilah ini awalnya dipakai Abu Bakar saat menyebut dirinya sebagai khalifah (pengganti) Nabi Muhammad. Lihat 
Dari berbagai istilah di atas, penyebutan negara dalam Islam memiliki beragam corak. Secara historis, istilah-istilah di atas pernah dipraktekkan oleh umat Islam di berbagai kawasan.

Relasi di sini berarti sebuah hubungan, yang kemudian melahirkan beberapa pendapat yang berbeda menyikapi pola relasi antara agama (Islam) dengan negara. Apakah negara harus tunduk di bawah dogma agama? apakah agama harus terkooptasi oleh negara? Apakah negara dan agama harus berhadapan secara frontal, tanpa harus saling mencampuri? Apakah agama dan negara diposisikan dalam ruang yang berbeda, namun saling menguntungkan? Atau agama dan negara harus dipersatukan? Inilah yang kemudian banyak melahirkan polemik sepanjang sejarah.

Dalam kajian historis, pembicaraan hubungan antara agama dan negara dalam Islam selalu terjadi dalam suasana yang stigmatis. Ini disebabkan, pertama, hubungan agama dan negara dalam Islam adalah yang paling mengesankan sepanjang sejarah umat manusia. Kedua, sepanjang sejarah, hubungan antara kaum Muslim dan non-Muslim Barat (Kristen Eropa) adalah hubungan penuh ketegangan. Dimulai dengan ekspansi militer-politik Islam klasik yang sebagian besar atas kerugian Kristen (hampir seluruh Timur Tengah adalah dahulunya kawasan Kristen) dengan

Said Agil Husin al-Munawwar, "Fiqh Siyasah dalam Konteks Perubahan Menuju Masyarakat Madan", Jurnal IImu Sosial Keagamaan, Vol I. No. I, 1999, 21.

${ }^{19}$ Pada dasarnya, teori imamah lebih berkembang di kelompok Shi'ah. Dalam lingkungan Shi'ah, imamah menekankan dua rukun, yaitu kekuasaan imam (wilayat) dan kesucian imam ("ismah). Lihat Mustafa Hilmi, Nizam al-Khilafah Baina Ahl al-Sunnah wa al-Syiah, (Iskandariah: Dar adDa'wah, 1988), 149-155.

20 Jika khilafah dan imamah berkorelasi dengan format politik atau kekuasaan, maka hukumah. berhubungan dengan sistem pemerintahan. Lihat John L. Esposito (ed.) The Oxford Encyclopedia Of The Modern Islamic World, Vol 4. Jilid II, (New York: Oxford University Press, 1995), artikel "hukumah." oleh. Keith Lewinstein, h. 139.

${ }^{21}$ Istilah ini diartikan wewenang. Muncul berkali-kali dalam al-Quran dengan arti "kekuasaan", kadang-kadang "bukti"-dan yang lebih khusus lagi-_"kekuasaan yang efektif", lazimnya diberi kata sifat mubin, "wewenang yang jelas". Di Nusantara, penguasa muslim diberi laqab Sultan. Lihat Kamaruzzaman, Relasi) Islam dan Negara: Perpektif Modernis \& Fundamentalis, (Magelang: Indonesia Tera, 200 I), 33. 
kulminasinya berupa pembebasan Konstantinopel (ibukota Eropa dan dunia Kristen saat itu), kemudian Perang Salib yang kalahmenang silih berganti namun akhirnya dimenangkan oleh Islam, lalu berkembang dalam tatanan dunia yang dikuasai oleh Barat imperialis-kolonialis dengan Dunia Islam sebagai yang paling dirugikan. Disebabkan oleh hubungan antara Dunia Islam dan Barat yang traumatik tersebut, lebih-lebih lagi karena dalam fasenya yang terakhir Dunia Islam dalam posisi "kalah", maka pembicaraan tentang Islam berkenaan dengan pandangannya tentang negara berlangsung dalam kepahitan menghadapi Barat sebagai "musuh".22

\section{Pemikiran KH.A.Wahid Hasyim tentang Agama dan Negara}

Salah satu masalah yang dihadapi oleh negeri yang mayoritas berpenduduk muslim pada awal pembentukannya adalah bagaimana mendudukkan agama dalam kehidupan bernegara. Dalam pandangan Deliar Noer, Islam setidaknya meliputi dua aspek pokok yaitu agama dan masyarakat atau politik. ${ }^{23}$ Akan tetapi, untuk mengartikulasikan dua aspek pokok tersebut dalam realitas menjadi suatu problem tersendiri.

Begitu pula tatkala Indonesia membangun hubungan antara agama dan politik. Kesulitan ini pernah diungkapkan oleh Zifirdaus Adnan. Ia menjelaskan bahwa hubungan ini begitu sulit sebab terdapat dua arus besar. Pertama, kelompok yang menghendaki adanya kaitan formal antara Islam dan Negarabaik dalam bentuk Negara Islam, Islam sebagai agama negara, atau negara yang memberlakukan ajaran Islam. Kedua, kelompok yang menantang kaitan antara Islam dan negara dalam bentuk apapun. ${ }^{24}$ Hubungan yang tidak harmonis ini terutama disebabkan oleh perbedaan pandangan para pendiri republik ini-yang sebagaian besar muslim-mengenai Indonesia yang dicita-citakan.

\footnotetext{
22 Nurcholish Madjid, Telaah atas Fiqh Siyasy Sunni, www.artikelislam.com

${ }^{23}$ Deliar Noer, Gerakan Modern Islam di Indonesia 1900- 1942, (Jakarta: LP3ES, 1996), I.

${ }^{24}$ Bahtiar Effendi, Teologi Baru Politik Islam, (Yogyakarta: Galang Press, 200 I), vii.
} 
Salah satu butir terpenting dalam perbedaan di atas adalah apakah negara Indonesia bercorak Islami atau nasionalis. ${ }^{25}$

Perdebatan berlangsung tatkala para founding fathers yang tergabung dalam BPUPKI (Badan Penyelidik Usaha-Usaha Persiapan Kemerdekaan Indonesia, Dokuritsu Zyunbi Tyoosakai) membahas bentuk dasar negara dan bentuk pemerintahan. ${ }^{26}$ Dari 62 anggota BPUPKI, terbagi dua arus besar; golongan nasionalis sekuler serta nasionalis Islami. Namun, dari jumlah itu, hanya $25 \%$ saja yang dianggap mewakili kepentingan Islam, selebihnya mewakili pandangan nasionalisme sekuler yang dalam hal ini enggan membawa agama dalam masalah kenegaraan. Sehingga tampaknya dukungan pemerintah pendudukan Jepang kepada Islam tak dapat lagi diharapkan. ${ }^{27}$

Perdebatan berlangsung dalam rapat anggota BPUPKI menyangkut dasar negara dan perumusan Undang-Undang dasar. Sebagai bagian dari kalangan nasionalis Islami yang dibesarkan di pesantren, saat itu KH.A. Wahid hasyim mengajukan usul penting; presiden harus orang Islam, serta mencanangkan Islam sebagai agama negara. Selain itu, kalangan nasionalis Islami juga menyodorkan naskah Piagam Jakarta yang akhirnya disetujui oleh dua kelompok nasionalis Islami dan sekuler.

Namun, pada tahapan berikutnya, tepatnya sehari setelah proklamasi, KH. A. Wahid Hasyim berubah pikiran. Ia malah mendukung usulan kalangan nasionalis sekuler dalam menghapus tujuh kata tersebut. Sungguhpun demikian, jika dilacak, di sinilah kebesaran jiwa seorang KH. A. Wahid Hasyim tampak menonjol. Ia mendahulukan kepentingan lebih besar dalam skala jangka panjang. Terjadi lompatan pemikiran pada diri KH. A. Wahid Hasyim. Ia lebih menekankan sisi substansi daripada tampilan

${ }^{25}$ Bahtiar Effendi, Islam dan Negara: Transformasi Pemikiran, 60.

${ }^{26}$ Endang Saifuddin Anshari, Piagam Jakarta 22 Juni 1945 dan Sejarah Konsensus, 26.

${ }^{27}$ Ibid., 26; Lihat pula Prawoto Mangkusasmito, Perumusan Historis Rumus Dasar Negara dan Sebuah Proyeksi, 12. Sebagai pembanding lihat juga Harry J. Benda, Bulan Sabit Dan Matahari Terbit, 222-244. 
formalitas. Ia lebih bijak menyikapi persoalan dasar negara, dan dalam menempatkan posisi Pancasila dalam struktur keberagamaan muslim Indonesia. Apa yang diperjuangkan A. Wahid Hasyim saat itu adalah melakukan upaya-upaya Islamisasi di segala bidang, terutama dalam konstitusi negara. Akan tetapi, tatkala ia menjumpai sebuah permasalahan besar yang menyangkut persatuan dan kesatuan umat, ia rela menanggalkan pendapat pribadinya, demi kemaslahatan umat.

Tampaknya, upaya yang dilakukan KH. A. Wahid Hasyim tidak hanya dipahami sebagai inkonsistensi dalam memperjuangkan shari'ah Islam yang ia perjuangkan. Tentunya, KH.A. Wahid Hasyim memiliki argumentasi kuat dalam melakukan penghapusan tujuh kata itu. Bahkan, tidak saja menerima Pancasila, ia lebih jauh ikut merumuskan Pancasila dan UUD 1945. ${ }^{28}$ Penerimaan dan pengamalan Pancasila, demikian urai Muchith Muzadi, merupakan perwujudan dari upaya umat Islam Indonesia dalam menjalankan shari'ah. ${ }^{29}$

Sebagai seorang yang dibesarkan di kalangan tradisionalis yang bercorak pemikiran Sunni, KH.A. Wahid Hasyim tentu saja banyak dipengaruhi oleh khazanah pemikiran klasik. Ditinjau dari segi pemikiran Nahdlatul Ulama yang mempengaruhinya, sikap KH.A. Wahid Hasyim memiliki konsistensi rasional. Dalam mengantisipasi gejala-gejala sosial politik, NU selalu melihatnya tidak dalam posisi mutlak-mutlakan. Salah satu prinsip yang digunakan adalah dalil ma la yudraku kulluh la yutraku kulluh, atau apa yang tidak bisa dicapai seluruhnya, elemen yang sudah dicapai tidaklah ditinggalkan. Inilah solusi secara fiqh yang menjadi bagian tak terpisahkan dari dinamika politik NU sepanjang sejarah Indonesia dan mencegahnya terperosok dalam berbagai bentuk radikalisme yang justeru kontraproduktif terhadap cita-cita agama dan negara bangsa. Apa yang dilakukan

\footnotetext{
${ }^{28}$ Saifuddin Zuhri, Keleidoskop Politik di Indonesia, jilid I, (Jakarta: Gunung Agung, 1987), 197.

${ }^{29}$ Ayu Sutarto, Menjadi NU Menjadi Indonesia: Pemikiran KH. A. Muchith Muzadi, (Surabaya: Khalista, 2008), 103.
} 
oleh KH. A.Wahid Hasyim dengan menerima Pancasila, merupakan implementasi dari sebuah doktrin fiqh tersebut. Tatkala negara Islam tak terbentuk, maka nilai-nilai Islam akan berusaha diakomodasi oleh Pancasila.

Pemikiran figh, dengan demikian, mencegah suatu cara pandang monokultural terhadap realitas dan pada saat yang sama menyediakan daerah sangga yang rasional bila tujuan keagamaan dalam wilayah politik mengalami jalan buntu. Pemikiran serba fiqh menyediakan jalan keluar tanpa harus terjebak dalam sikapsikap yang ekstrem. Selain itu, wujud formal negara yang telah memenuhi kualifikasi menurut shari'ah, yang secara de jure diputuskan dalam Muktamar NU di Banjarmasin pada 1936, merupakan perintah agama yang harus diikuti. ${ }^{30}$

Dalam babakan sejarah berikutnya, misalnya, para ulama NU misalnya pernah memperjuangkan agar shari'ah bisa dimasukkan dalam undang-undang negara pada sidang-sidang Konstituante 1958-1959. Namun, ketika usaha ini menemui jalan buntu, maka mereka tidak menolak eksistensi UUD 1945 dan Indonesia sebagai negara bangsa, tetapi menerimanya sebagai realitas politik dengan penuh kesungguhan, terutama karena umat Islam diberi kebebasan untuk menjalankan ajaran agamanya.

Dalam konteks itu, penerimaan Wahid Hasyim terhadap Pancasila $^{31}$ dan UUD 1945, sekali lagi, merupakan antisipasi umat Islam untuk memperoleh yang "sebagian", sebab untuk memperoleh "semua", atau menjadikan Indonesia sebagai negara Islam, barangkali akan menghadapi kesulitan besar di kemudian hari, mungkin juga akan menjadi bumerang bagi umat Islam, dikarenakan begitu pluralnya agama, budaya, dan kehidupan sosial di Indonesia. Begitu pula tatkala memisahkan agama dari

\footnotetext{
30 M. Ali Haidar, NU : Wawasan Sosio-Kultural dan Keagamaan, Majalah Aula, Maret 1994

31 Bahkan dengan "berani", Abdurrahman Wahid menyebut ayahnya telah "..mempertahankan kedudukan Pancasila dengan supremasinya atas hukum Islam (Shariah)". Lihat "A.Wahid Hasyim, NU, dan Islam", dalam Imam Anshori Sholeh, Islam, Negara, Dan Demokrasi: Himpunan Percikan Perenungan Gus Dur, (Jakarta: Erlangga, 1999), I4- 15.
}

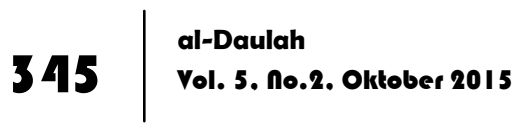


negara, hal itu akan melepaskan agama dari tanggung jawab atas berbagai ketidakadilan dan tragedi kemanusiaan. Agama juga menjadi tidak bertanggung jawab atas kedzaliman penguasa. ${ }^{32}$

Dua alasan penerimaan KH. A. Wahid Hasyim terhadap Pancasila adalah kondisi saat itu yang sangat membutuhkan persatuan untuk menghadapi Belanda yang berusaha kembali ke daerah jajahan mereka. Alasan lainnya adalah bahwa bahwa kewajiban mengikuti shari'ah Islam bagi umat Islam akan mendapatkan tempatnya dalam penerapan yang jujur terhadap pasal 29 UUD 1945 yang menjamin kebebasan setiap warga negara untuk memeluk agama dan mengamalkan menurut agamanya masing-masing. ${ }^{33}$

Dalam alasan pertama, KH.A. Wahid Hasyim tampaknya menggunakan kaidah dar al-mafasid muqaddam ala jalb al-mashalih; mendahulukan upaya menghindari bahaya atau kerusuhan daripada melaksanakan kemaslahatan yang lebih besar. Bisa jadi, kaidah ini juga didukung dengan kaidah lain, idza ta'ararad almafsadatani ru'iya a'dzamuha dhararan bi irtika bi akhaffihima; apabila terjadi kemungkinan komplikasi bahaya maka dipertimbangkan bahaya yang lebih besar resikonya, dengan melaksanakan yang paling kecil resikonya. Kedua kaidah ini mendahulukan upaya preventif menghindari bahaya daripada melaksanakan kemaslahatan yang lebih tinggi.

Dengan mempertimbangkan usia republik yang baru diproklamirkan, ia menghindari resiko perpecahan, terutama dengan kawasan Indonesia Timur maupun dengan umat beragama lain, dengan konsekwensi permintaan menghapus tujuh kata dalam Piagam Jakarta. Padahal, yang dibutuhkan saat itu adalah persatuan, bukan perpecahan yang diakibatkan perbedaan sektarian. Dengan demikian, polarisasi dan friksi akut yang akan terjadi di kalangan internal umat Islam maupun kelompok non-

32 M. Zaid Wahyudi, Relasi Antara Agama dengan Negara di Indonesia, Kompas, Selasa, 26 Juni 2007

${ }^{33}$ Saifuddin Zuhri, Berangkat dari Pesantren, (Jakarta: Gunung Agung, 1987), 302. 
muslim, jika ia tetap bersikukuh mempertahankan pendapatnya, bisa dihindari.

Padahal, sebagaimana Boland ${ }^{34}$ anak kalimat tersebut sangat penting artinya pada tahun-tahun berikutnya karena memberikan peluang kepada masyarakat Islam yang berusaha keras melaksanakan cita-cita negara Islam dengan cara konstitusional. Intinya, Piagam Jakarta adalah "pintu" menuju Negara berdasarkan Islam, sebagaimana yang dikehendaki KH.A. Wahid Hasyim bersama kelompok nasionalis Islam dalam sidang BPUPKI. Tapi, kalangan nasionalis Islam memilih "mengalah".

Seperti diungkapkan kepada Saifuddin Zuhri (mantan Menteri Agama), KH. A. Wahid Hasyim di dalam pertemuan 18 Agustus 1945 itu menyatakan bahwa kelompok minoritas bisa melakukan politik ofensif, bahkan disertai dengan "ancaman" karena mereka merasa tertindas. Tetapi sebagai kelompok yang mempunyai kepentingan atas kokohnya persatuan untuk menghadapi Belanda, para pemimpin Islam dan para nasionalis sudah sepatutnya memenuhi keinginan itu. Menurut KH. A. Wahid Hasyim, penerapan shari'ah Islam boleh ditampung melalui pelaksanaan Pasal 29 Ayat 2 UUD 1945 secara jujur. Apabila aturan yang menjamin kemerdekaan beragama dan beribadah ini dijalankan dengan baik, maka berarti sudah semestinya kewajiban menjalankan shari'ah Islam akan tumbuh sebagai kesadaran setiap Muslim. ${ }^{35}$

Bagi KH. A. Wahid Hasyim, yang harus diterima dan yang terpenting adalah yang di "dalam" Indonesia, yaitu adanya negara yang memungkinkan kaum muslimin melaksanakan ajaran agama mereka secara nyata. ${ }^{36}$ Dengan demikian, pemberlakuan shari'ah

\footnotetext{
${ }^{34}$ B.J Boland, Pergumulan Islam di Indonesia, 72.

${ }^{35}$ Feillard, NU Vis a Vis Negara, (Yogyakarta: LkiS, 2008), 40-41.

${ }^{36}$ Tampaknya pendapat Wahid Hasyim itu dipengaruhi oleh keputusan Nahdlatul Ulama pada Muktamar NU di Banjarmasin pada 1936 yang memutuskan bahwa kawasan Hindia Belanda telah memenuhi syarat sebagai Dar al-Islam (Negara Islam). Selengkapnya lihat Imam Ghazali Said \& A. Ma'ruf Asrori, Solusi Problematika Aktual Hukum Islam: Keputusan Muktamar, Munas, dan Konbes NU (1926-1999) Diantama, 2004, 185. Bandingkan dengan M. Ali Haidar,
} 
adalah melalui cara persuasif, 37 atau etika sosial dalam istilah Abdurrahman Wahid. ${ }^{38}$

Dalam hal ini, jika ditinjau dari aspek fiqh, upaya yang telah dilakukan oleh KH. A. Wahid Hasyim telah melaksanakan dua aspek penting dalam pemerintahan Islam. Adapun dalam aspek intenal, negara berkuasa penuh atas semua individu dan instusiinstusi yang ada dalam negara Islam. Rakyat wajib taat sepenuhnya kepada pemerintah sepanjang masih dalam batasbatas shari'ah. Nabi SAW berkata :

$$
\text { لا طاعة في معصية الله ,إنما الطاعة في المعروف }
$$

"Tidak wajib metaati perintah yang mengandung maksiat kepada Allah, ketaatan hanya ada dalam hal kebaikan." (Hadits riwayat Imam Muslim dari Sahabat Ali RA)

Dalam aspek ini, al-Mawardi menjelaskan apabila imam (kepala negara) telah menjalankan semua tugas-tugasnya dalam memenuhi hak-hak rakyatnya dan menegakkan hak-hak Allah SWT diantara mereka, maka wajib bagi rakyatnya memenuhi dua hak sang imam yaitu : hak mentaatinya dan hak membantu tugasnya. ${ }^{39}$

Sebagai seorang nasionalis yang akrab dengan nilai-nilai Islam, Wahid Hasyim berusaha menjalani kehidupan sebagai seorang negarawan, juga sebagai seorang muslim. Sebagai negarawan, ia tak mau persatuan bangsa Indonesia terkoyak dengan adanya pemberontakan di berbagai daerah. Pada gerakan

Nahdlatul Ulama dan Islam di Indonesia: Pendekatan Fikih dalam Politik, Jakarta: Gramedia Pustaka Utama, 1998), 319-324; dan Hasbullah Bakri, Bunga Rampai Tentang Islam, Negara, dan Hukum, (Jakarta: Pedoman IImu Jaya, 1987), 32-4I.

${ }^{37}$ Metode pemberlakuan Shariah melalui jalan substantif di masyarakat, serta kritiknya terhadap pola dakwah di masa itu, dapat dilihat dalam pidatonya yang berjudul "Analisis Kelemahan Penerangan Islam", dalam Buntaran Sanusi (Ed.), A.Wahid Hasyim, Mengapa Memilih NU..,h. | $42-144$

${ }^{38}$ Baca selengkapnya dalam Abdurrahman Wahid, Islamku, Islam Anda, Islam Kita; Agama Masyarakat, dan Demokrasi, (Jakarta: The Wahid Institute, 2007), terutama pada Bab II, "Islam, Negara, dan Kepemimpinan Ummat"

${ }^{39}$ Al-Mawardi, al Ahkam A/ Sulthaniyah, 15 
oposisi Angkatan Umat Islam di Kebumen, Wahid Hasyim selaku Menteri Agama berusaha mendatangi mereka guna mengajak menghentikan perlawanan. ${ }^{40}$ Bahkan, konon, ia sempat diculik oleh anak buah Kahar Muzakkar, guna dimintai pertimbangan dan nasehat. Begitu pula tatkala nama KH. A. Wahid Hasyim dicatut oleh Tan Malaka sebagai salah satu calon menteri jika upaya kudeta yang dilakukannya berhasil, KH. A. Wahid Hasyim sontak terkejut dan tak menyetujui upaya kudeta yang dilakukan Chaerul Saleh dan Tan Malaka, sahabat eratnya itu. ${ }^{41}$

Apa yang dikehendaki Wahid Hasyim dalam memandang posisi negara adalah, bahwa negara memiliki peranan penting sebagai sebuah "kesepakatan" dari berbagai elemen bangsa. Untuk itulah, ia bersikukuh mempertahankan persatuan dan keutuhan bangsa. Ia juga bersedia menerima Pancasila sebagai dasar negara karena di samping Pancasila dianggap baik (mashlahat) Islam juga juga harus memberi motivasi untuk menerima, bukan hanya Pancasila, tetapi juga apa yang baik yang dapat memberikan kontribusi bagi perwujudan nilai-nilai Islam secara konkrit. ${ }^{42}$

Dalam menilai negara, KH. A. Wahid Hasyim bisa dikategorikan seorang substansialis, yang berpandangan relasi agama dan negara sebagai hubungan yang simbiosis mutualistik. Dalam pandangannya, negara sekedar melayani keperluan agama rakyat sesuai dengan dasar Pancasila. Terhadap persoalan yang bersifat individual, menurut KH.A. Wahid Hasyim, pemerintah tidak boleh mencampurinya dan hanya boleh mengatur persoalan agama pada segi yang berifat kemasyarakatan. ${ }^{43}$ Mengenai perkara khusus yang terjadi pada suatu golongan agama, seperti

\footnotetext{
${ }^{40}$ Cornelis Van Dick, Darul Islam: Sebuah Pemberontakan, (Jakarta: Grafiti Press, 1983), 137.

${ }^{41}$ Saifuddin Zuhri, Berangkat dari Pesantren, 3 । 3.

42 Nurcholis Madjid, "Pembahasan Atas makalah KH. Achmad Siddiq, Hubungan Agama dan Pancasila" dalam Peranan Agama dalam Pemantapan Ideologi Negara Pancasila, (Jakarta: Departemen Agama RI, 1984), 37.

${ }^{43}$ K.H.A. Wahid Hasyim, "Tugas Pemerintah Terhadap Agama", dalam Buntaran Sanusi (ed.), Mengapa Memilih NU, 148.
} 
mendirikan masjid, gereja, dan rumah ibadah lainnya, bukan menjadi urusan pemerintah.

KH. A. Wahid Hasyim berpendapat bahwa relasi sekularistik agama-negara hanya bersifat teori saja, dan tidak pernah berlaku di mana pun kecuali bagi mereka yang atheis. ${ }^{44}$ Ia juga mengkritik pola relasi integralistik antara agama dan negara. Kekeliruan paham ini, menurut KH. A. Wahid Hasyim, timbul dari teori persatuan antar negara dan agama yang dipegang oleh sebagian masyarakat Indonesia saat itu. Bahkan menurutnya pemerintah Indonesia pada dasarnya menyetujui pemisahan antara agama dan negara dalam arti bahwa pemerintah tidak campur tangan urusan dalam suatu agama, kecuali dalam urusan tertentu. ${ }^{45}$

Karena itu, dari sudut pandang umat Islam, Pancasila, menurut Abdurrahman Wahid, adalah upaya maksimal warga muslim Indonesia untuk menyelamatkan bentuk negara di tengah tarikan keinginan membuat dasar negara sekuler dan Islam. Pancasila bagi umat Islam adalah dasar negara, sedangkan Islam adalah akidahnya. Pancasila mengatur tata hidup bernegara, sedangkan tata hidup beragama diatur oleh Islam. Keduanya tidak akan berbenturan dan tidak perlu dibenturkan, sehingga menurut Gus Dur, Islam tidak perlu menjadi agama resmi negara dan diformalisasikan dalam bentuk undang-undang negara, tetapi yang penting adalah jaminan negara bagi umat Islam untuk menjalankan agamanya. ${ }^{46}$

Meskipun ada sebagian rakyat Indonesia yang berkeinginan menghidupkan shari'ah Islam dengan mewujudkan negara Indonesia sebagai negara Islam, namun dengan lahirnya Republik Indonesia semuanya harus bisa menerima. Sebab yang terpenting di dalamnya, menurut KH. A. Wahid Hasyim, adalah kaum Muslimin dapat melaksanakan ajaran agamanya secara nyata. Dicantumkannya sila Ketuhanan Yang Maha Esa dan dasar

\footnotetext{
${ }^{44}$ Kementerian Agama dan Parlemen, 4I.

${ }^{45}$ K.H.A. Wahid Hasyim, "Tugas Pemerintah, 148.

${ }^{46}$ Abdurrahman Wahid, Mengurai Hubungan Agama dan Negara, 19.
} 
demokrasi (kedaulatan rakyat) dalam Pancasila memberikan pegangan kepada bangsa Indonesia untuk memberikan kebebasan dan kemerdekaan suatu golongan kepada golongan lain. Pertemuan dua prinsip ini, lanjutnya, mengakibatkan adanya kompromi; keinginan kaum Muslimin untuk menghidupkan shari'ah agamanya tetap diberi jalan, tetapi prinsip demokrasi juga dipertahankan agar keinginan tadi tidak mendesak dan merugikan golongan lain . ${ }^{47}$

Hal ini tampaknya sesuai dengan apa yang dikatakan Abdelwahab el-Affendi, bahwa negara akan sesuai dengan shari'ah yang tak dipaksakan, tetapi merupakan sebuah ekspresi sesungguhnya dari kehendak masyarakat tersebut. Dengan keanggotaan yang benar-benar bebas, masyarakat muslim di jantung negara ini merupakan masyarakat yang memilih untuk hidup sesuai dengan Islam dan mentaati shari'ah. Ketaatan ini secara esensial merupakan masalah hati nurani. Karena itu, shari'ah benar-benar ditaati hanya bila rakyat melakukannya secara sukarela dan tulus. ${ }^{48}$

\section{Relevansi Pemikiran KH. A. Wahid Hasyim dengan Kondisi Sekarang}

Sejarah mencatat bahwa gerakan-gerakan nasionalis sekuler lebih mendominasi pemerintahan di Indonesia, terutama pada pemerintahan represif Orde Baru. Salah satunya, Pancasila dijadikan alat penguasa untuk bertindak represif terhadap kelompok penentang kebijakan pemerintah dengan tudingan tidak "Pancasilais". Pancasila dijadikan alat penyeragaman Indonesia yang majemuk. ${ }^{49}$ Akibatnya, gerakan-gerakan Islam, terutama yang berkaitan dengan politik, bergerak secara eksklusif dan klandestein.

\footnotetext{
${ }^{47}$ K.H.A. Wahid Hasyim, "Tugas Pemerintah, dalam Sanusi (Ed), I 48.

${ }^{48}$ Abdelwahab el-Affendi, Masyarakat Tak Bernegara: Kritik Teori Politik Islam, (Yogyakarta: LkiS, 200I), 94.

${ }^{49}$ M. Zaid Wahyudi, Relasi Agama dan Negara yang Terus Digugat, Kompas, Selasa, 26 Juni 2007
}

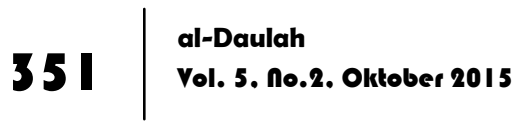


Akibatnya, tatkala Orde Baru runtuh pada 1998, gerakangerakan politik yang mengusung wacana-wacana "Islam politik", kembali marak. Masa transisi ini sekaligus menjadikan pertanyaan besar seiring dengan ambruknya bangunan politik lama dan belum tercapainya bangunan politik yang baru. Dalam konteks relasi Islam dan negara, di mana keberadaan NKRI dengan dasar Pancasila telah dianggap final, kemudian ikut ambruk seiring dengan munculnya berbagai penfsiran baru terhadap bentuk negara dan dasar negara.

Termasuk "menghidupkan" kembali Piagam Jakarta, kembali semarak. Parpol yang mengidentikan diri dengan Islam seperti seperti Partai Persatuan Pembangunan (PPP), Partai Bulan Bintang (PBB), dan Partai Keadilan Sejahtera (PKS), berupaya memasukkan Piagam Jakarta dalam amandemen UUD pada tahun 1999. Di luar parlemen, upaya menghidupkan shari'ah Islam dalam negara getol dilakukan oleh ormas keagamaan seperti Hizbut Tahrir Indonesia (HTI), Majelis Mujahidin Indonesia (MMI), hingga Front Pembela Islam (FPI), hingga saat ini.

Upaya menampilkan hukum Islam secara formal, pernah dilakukan golongan nasionalis Islami, pada pembahasan dasar negara pada zaman pra kemerdekaan. KH. A. Wahid Hasyim, salah satu tokoh Islam terkemuka saat itu, menginginkan Islam dijadikan dasar negara Indonesia. Ia begitu kukuh memperjuangkan cita-citanya. Akan tetapi, pada 18 Agustus 1945, ia memprakarsai penghapusan tujuh kata dalam Piagam Jakarta.

Dalam penghadapan dengan kekuasaan dan negara, Islam di Indonesia sering berada pada posisi dilematis. Dilema yang dihadapi menyangkut tarik-menarik antara tuntutan untuk aktualisasi diri secara determinan sebagai kelompok mayoritas dan kenyataan kehidupan politik yang tidak selalu kondusif bagi aktualisasi diri tersebut. Sebagai akibatnya, politik Islam dihadapkan pada beberapa pilihan strategis yang masing-masing mengandung konsekuensi dalam dirinya. 
Pertama, strategi akomodatif justifikatif terhadap kekuasaan negara yang sering tidak mencerminkan idealisme Islam dengan konsekuensi menerima penghujatan dari kalangan "garis keras" umat Islam. Kedua, strategi isolatif-oposisional, yaitu menolak dan memisahkan diri dari kekuasaan negara untuk membangun kekuatan sendiri, dengan konsekuensi kehilangan faktor pendukungnya, yaitu kekuatan negara itu sendiri, yang kemudian dikuasai dan dimanfaatkan oleh pihak lain. Ketiga, strategi integratif-kritis, yaitu mengintegrasikan diri ke dalam kekuasaan negara, tetapi tetap kritis terhadap penyelewengan kekuasaan dalam suatu perjuangan dari dalam. Namun, strategi ini sering berhadapan dengan hegemoni negara itu sendiri, sehingga efektifitas perjuangannya dipertanyakan.

Salah satu isu politik yang sering menempatkan kelompok Islam pada posisi dilematis yang sering dihadapi politik Islam adalah pemosisian Islam vis a vis negara yang berdasarkan Pancasila. Walaupun umat Islam mempunyai andil yang sangat besar dalam menegakkan negara melalui perjuangan yang panjang dalam melawan penjajahan dan menegakkan kemerdekaan, namun untuk mengisi negara merdeka kelompok Islam tidak selalu pada posisi yang menentukan.

Gagasan A. Wahid Hasyim sebenarnya didasarkan pada prinsip tujuan dan cara pencapaiannya (al-Ghayah wa al-Wasail) untuk melihat pentingnya aspek fungsionalisasi ajaran agama. Dalam konteks inilah kemudian KH. A. Wahid Hasyim berupaya untuk memberikan solusi atas ketegangan antara dua kutub yang berbeda; yaitu antara nasionalis Islam dan nasionalis sekuler maupun antara mereka yang menginginkan Islam sebagai dasar negara dan menginginkan sekulerisme tumbuh di Indonesia.

KH. A.Wahid Hasyim, secara tak langsung ingin menjadikan Islam sebagai etika sosial dalam kehidupan bernegara. Pemikiran ini kemudian lebih cenderung pada kedekatan pada paradigma simbiotik dimana negara dan agama saling menunjang. Yaitu menempatkan Islam sebagai faktor komplementer dalam 
kehidupan sosio-kultural. Keyakinan ini, didasarkan atas pehamanan mengenai relasi negara dan agama dalam pemikiran Ibnu Khaldun, yang menganggap pembentukan sebuah negara disamping paham keagamaan, juga diperlukan rasa ashabiyah (perasaan keterikatan atau perasaan kelompok). Perasaan ikatan sebagai satu kelompok ini tampak dalam berbagai artikel maupun pidato KH. A. Wahid Hasyim.

Dengan demikian diskursus relasi negara dan agama memang ada dalam dialektika Islam. Hal inilah yang kemudian tidak bisa dijustifikasi kebenarannya yang mana yang benar atau yang mana yang salah. Hanya saja sebagai solusi alternatif, bagaimana kemudian masyarakat bisa mendapatkan keadilan dan kesejahteraan dalam bernegara, dimana hal inilah yang dijelaskan dalam kehidupan agama, khususnya Islam. Inilah salah satu pemikiran KH. A.Wahid Hasyim yang relevan hingga kini.

Meskipun lahir dan tumbuh di lingkungan santrii ${ }^{50}$ tradisionalis ${ }^{51}$, Wahid Hasyim jauh dari konotasi pemikir konservatif, statis, dan ortodoks. Sebaliknya, ia dikenal sebagai sosok dinamis, visioner, progresif, bahkan liberal. ${ }^{52}$

${ }^{50}$ Istilah santri dalam konteks budaya Islam Indonesia telah lama dikenal. Keberadaannya selalu terkait erat dengan pesantren dimana elemen primernya adalah kiai dan santri. Istilah santri menjadi populer manakala Clifford Geertz, antropolog Amerika, meneliti tradisi dan budaya Jawa di Mojokuto (nama samaran untuk Kota kecil Pare di Kediri). Dalam penelitiannya, Geertz memberikan kategorisasi terhadap masyarakat Jawa, yaitu santri, abangan, dan priyayi. Lebih lanjut lihat Clifford Geertz, Abangan, Santri, dan Priyayi Dalam Masyarakat Jawa. Adapun perhatian mendalam terhadap dunia pesantren ada dalam Zamakhsyari Dhofier, Tradisi pesantren: Studi Tentang Pandangan Hidup Kiai, (Jakarta: LP3ES, 1982).

5) Dikotomi santri modernis dan tradisionalis ini nampak dalam karya Deliar Noer, Gerakan Modern di Indonesia.

52 Kosa kata liberal penulis dapatkan dari Abdurrahman Wahid, putra Wahid Hasyim, tatkala wawancara tanggal 3 Januari 2009 di PBNU Jakarta. Pandangan Gus Dur tentang sang ayah juga tampak dalam KH. A. Wahid Hasyim dalam Pandangan Dua Puteranya; Dialog Antara Gus Dur-Gus Sholah Mengenai Pandangan Politik Sang Ayah. (Jakarta: Forum Nahdliyyin untuk Kajian Strategis, 1998), Saifullah Ma'shum (ed). Juga Abdurrahan Wahid, "KH.A.Wahid Hasyim, NU dan Islam" dalam Islam, Negara, dan Demokrasi: Himpunan Percikan Perenungan Gus Dur, Imam Anshari Sholeh (ed.), 13-24. Sedangkan Andree Feillard hanya menyebut Wahid Hasyim telah "....memberikan penafsiran liberal terhadap Piagam Jakarta", lihat Andree Feillard, NU vis a vis Negara, 41 . 
Dalam pandangan Nurcholis Madjid, penghapusan tujuh kata dalam Piagam Jakarta, tidaklah dipahami sebagai kekalahan golongan nasionalis Islami melawan nasionalis sekuler. Justru itu adalah kemenangan politik wakil-wakil Muslim, dan bahkan kemenangan kaum Muslim di Indonesia. Menurut Madjid, dari pandangan bahwa Islam menghendaki para pengikutnya untuk berjuang bagi kebaikan universal (rahmatan li al-alamin), dan kembali ke keadaan nyata Indonesia, maka sudah jelas bahwa sistem yang menjamin kebaikan konstitusional bagi keseluruhan bangsa ialah sistem yang telah kita sepakati bersama, yakni pokokpokok yang terkenal dengan Pancasila menurut semangat UUD 1945. Madjid menegaskan bahwa hal stereotipikal ini penting dan terpaksa harus sering dikemukakan, terutama karena hal itu menyangkut persoalan pokok yang untuk sebagian masyarakat Muslim dianggap belum selesai benar. Padahal menurut Madjid, kaum muslim di Indonesia seharusnya tidak perlu menolak Pancasila (dan UUD 1945) karena ia sudah sangat Islami. Sifat Islami keduanya didasarkan pada 2 pertimbangan yakni: Pertama, nilai-nilainya dibenarkan oleh ajaran agama Islam, dan kedua, fungsinya sebagai noktah-noktah kesepakatan antar berbagai golongan untuk mewujudkan kesatuan sosial-politik bersama.

Harus diakui, sintesa antara negara dan agama di Indonesia menunjukkan jalan yang rumit, namun unik. Hingga kini, polemik masih terjadi untuk sekedar menebut republik Indonesia sebagai negara dengan klasifikasi seperti apa; bukan integralistik, juga bukan sekuler. Mungkin yang paling tepat adalah dengan menyebutnya sebagai negara simbiotik; negara dan agama saling menopang dan mengisi, tanpa saling berhadapan secara konfrontatif. Lebih tepat kiranya, jika relasi antara agama dengan negara di Indonesia menganut model middle way (jalan tengah), di mana negara mengakui eksistensi agama dalam konstitusinya dan pada saat yang sama politik agama tidak menguasai negara. 


\section{Penutup}

Dalam menilai relasi agama dan negara, KH. A. Wahid Hasyim bisa dikategorikan seorang substansialis, yang berpandangan relasi agama dan negara sebagai hubungan yang simbiosis mutualistik. KH. A. Wahid Hasyim berpendapat bahwa relasi sekularistik agama-negara hanya bersifat teori saja, hanyalah teori an sich, sebab manusia memerlukan agama untuk mengarungi kehidupan, dan teori ini tidak pernah berlaku di mana pun kecuali bagi orang atheis. Ia juga mengkritik pola relasi integralistik antara agama dan negara. Menurutnya pemerintah Indonesia pada dasarnya menyetujui pemisahan antara agama dan negara dalam arti bahwa pemerintah tidak campur tangan urusan dalam suatu agama, kecuali dalam urusan tertentu. KH. A. Wahid Hasyim memiliki tipikal pemikir yang substansialis, yang menghendaki agar agama ditempatkan dalam posisi strategis dalam kehidupan bernegara. Pemikirannya dupengaruhi oleh pemikiran politik yang bercorak Sunni klasik, sesuai dengan latar belakangnya yang dari kalangan pesantren.

Relevansi pemikiran KH. A. Wahid Hasyim tentang relasi agama dan negara terletak pada upayanya membuat peranan agama dan negara secara seimbang, saling memberi dan melengkapi. Islam tetap membutuhkan negara untuk melindungi kebebasan warganya menjalankan agamanya, sedangkan negara butuh legitimasi agama untuk membuat seperangkat peraturan demi mencapai kemaslahatan. Pada dimensi yang sama, relevansinya terletak pada gagasannya untuk tetap mendahulukan kepentingan bersama dibandingkan dengan kepentingan pribadi. Sikap dan pandangan moderat (tawazun), toleran (tasamuh), mengambil jalan tengah (tawassuth), dan bersikap adil (i'tidal), yang dianut merupakan pilihan tepat yang inklusif dan akomodatif dalam kehidupan berbangsa dan bernegara. Dengan demikian, sikap dan pendangannya masih relevan untuk diimplementasikan dalam kondisi sekarang. 


\section{Daftar Pustaka}

Abdillah, Masykuri. Demokrasi di Persimpangan Makna: Respon Intelektual Muslim Indonesia Terhadap Demokrasi (1966-1993). Yogyakarta: Tiara Wacana, 1999.

Anshari, Endang Saifuddin. Piagam Jakarta 22 Juni 1945 dan Sejarah Konsensus Nasional Antara Nasionalis Islami dan Nasionalis Sekular Tentang Dasar Negara Republik Indonesia 1945-1959. Bandung: Penerbit Pustaka, 1983.

Atjeh, Aboebakar. Sejarah Hidup K.H.A. Wahid Hasyim dan Karangan Tersiar. Jakarta: Panitia Buku Peringatan Alm. K.H.A. Wahid Hasyim, 1957.

Bakri, Hasbullah. Bunga Rampai Tentang Islam, Negara dan Hukum. Jakarta: Pedoman Ilmu Jaya, 1987.

Basori, Rochman. The Founding Father Pesantren Modern Indonesia; Jejak Langkah KH. A. Wahid Hasyim. Banten: Inceis, 2006.

Benda J, Harry. Bulan Sabit Dan Matahari Terbit: Islam Indonesia Pada Masa Pendudukan Jepang. Jakarta: Pustaka Jaya, 1980.

Boland, B.J. Pergumulan Islam di Indonesia 1945-1972. Jakarta: Grafiti Press, 1985.

Dahlan, Abdul Aziz. Ensiklopedi Hukum Islam. Jilid I. Jakarta: Ichtiar Baru van Hoeve, 1996.

Dhofier, Zamakhsyari. Tradisi Pesantren: Studi Tentang Pandangan Hidup Kiai. Jakarta: LP3ES, 1982.

Effendi, Bahtiar. Islam dan Negara: Transformasi Pemikiran dan Praktik Politik Islam di Indonesia. Jakarta: Paramadina, 1998. -. Teologi Baru Politik Islam. Yogyakarta: Galang Press, 2001.

El-Affendi, Abdelwahab. Masyarakat Tak Bernegara: Kritik Teori Politik Islam. Yogyakarta: LkiS, 2001.

Esposito, John L. (ed.) The Oxford Encyclopedia Of The Modern Islamic World. Vol 4. Jilid II. New York: Oxford University Press, 1995.

Feillard, Andree. NU vis a vis Negara. Yogyakarta: LkiS, 2008. 
Haidar, M. Ali. "NU: Wawasan Sosio-Kultural dan Keagamaan". Majalah Aula, Maret 1994.

- Nahdlatul Ulama dan Islam di Indonesia: Pendekatan Fikih dalam Politik. Jakarta: Gramedia Pustaka Utama, 1998.

Hanafi, Ahmad A. Hafizar. Tata Negara. Jakarta: Yudhistira, 1995.

Hilmi, Mustafa. Nizam al-Khilafah Baina Ahl al-Sunnah wa al-Syiah. Iskandariah: Dar ad-Da'wah, 1988.

Kamaruzzaman. Relasi Islam dan Negara: Perpektif Modernis $\mathcal{E}$ Fundamentalis. Magelang: Indonesia Tera, 2001.

Ma'shum, Saifullah (ed). Menapak Jejak Mengenal Watak: Sekilas Biografi 26 Tokoh Nahdlatul Ulama. Jakarta: Yayasan Saifuddin Zuhri, 1994. KH. A. Wahid Hasyim dalam Pandangan Dua Puteranya; Dialog Antara Gus Dur-Gus Sholah Mengenai Pandangan Politik Sang Ayah. Jakarta: Forum Nahdliyyin untuk Kajian Strategis, 1998.

Madjid, Nurcholis. "Pembahasan Atas makalah KH. Achmad Siddiq, "Hubungan Agama dan Pancasila" dalam Peranan Agama dalam Pemantapan Ideologi Negara Pancasila. Jakarta: Departemen Agama RI, 1984.

. Telaah atas Figh Siyasy Sunni, dalam www.artikelislam.com

Mangkusasmito, Prawoto. Perumusan Historis Rumus Dasar Negara dan Sebuah Proyeksi. Jakarta: Hudaya, 1970.

Munawwar, Said Agil Husin. "Fiqh Siyasah, Konteks Perubahan Menuju Masyarakat Madani". Jurnal Ilmu Sosial Keagamaan, Vol I. No.1, 1999.

Nasution, Harun. Islam Ditinjau dari Berbagai Aspeknya. Jakarta: UI Press, Jilid I, Vol I, 1974.

Noer, Deliar. Gerakan Modern Islam di Indonesia 1900-1942. Jakarta: LP3ES, 1996.

Said, Imam Ghazali \& A. Ma'ruf Asrori. Solusi Problematika Aktual Hukum Islam: Keputusan Muktamar, Munas, dan Konbes NU (1926-1999). Diantama, 2004.

Santoso, Listiono. Teologi Politik Gus Dur. Yogyakarta: Arruz Press, 2004. 
Sholeh, Imam Anshari (ed.). Islam, Negara, Dan Demokrasi: Himpunan Percikan Perenungan Gus Dur. Jakarta: Erlangga, 1999.

Sjadzali, Munawir. Islam Dan Tata Negara; Ajaran, Sejarah Dan Pemikiran. Jakarta: UI Press, 1993.

Sutarto, Ayu. Menjadi NU Menjadi Indonesia: Pemikiran KH. A. Muchith Muzadi. Surabaya: Khalista, 2008.

Sutjianingsih. KH. A.Wahid Hasyim. Jakarta: Depdikbud, 1984.

Syamsudin, M. Din. “Usaha Pencarian Konsep Negara dalam Sejarah pemikiran Politik Islam". Jurnal Ulumul Quran, No. 2, Vol IV, th 1992.

Tim Penyusun. Kamus Pusat Pembinaan dan Pengembangan Bahasa. Jakarta: Balai Pustaka, 1994.

Wahid, Abdurrahman. Islamku, Islam Anda, Islam Kita. Jakarta: The Wahid Institute, 2007.

Wahyudi, M. Zaid. Relasi Antara Agama dengan Negara di Indonesia. Kompas, Selasa, 26 Juni 2007.

Van Dick, Cornelis. Darul Islam: Sebuah Pemberontakan. Jakarta: Grafiti Press, 1983.

Zaini, Achmad. Kyai Haji Abdul Wahid Hasyim; His Contribution To Moslem Educational Reformand Indonesian Nationalism During The Twentith Century. Yogyakarta: Titian Ilahi Press, 1998.

Zuhri, Saifuddin. Berangkat dari Pesantren. Jakarta: Gunung Agung, 1987.

-------. Keleidoskop Politik di Indonesia. Jilid I. Jakarta: Gunung Agung, 1987.

-------. Guruku Orang-Orang Dari Pesantren. Yogyakarta: Yayasan Saifuddin Zuhri dan LkiS, 2001. 